\title{
Hubungan antara kecerdasan emosi dengan perilaku agresif remaja dan implikasinya dalam bimbingan dan konseling
}

\author{
Ulya Illahi ${ }^{1}$, Neviyarni $\mathbf{S}^{2}$, Azrul Said ${ }^{3}$, Zadrian Ardi ${ }^{4}$ \\ ${ }^{12}$ Universitas Negeri Padang
}

\begin{abstract}
Abstrak
This research is motivated by the number of adolescents who behave aggressively, such as hitting, kicking, yelling, cursing, slandering. Aggressive behavior is an action that aims to hurt other people both physically and verbally. One of the factors that is thought to influence aggressive behavior is emotional intelligence. This study aims to: (1) describe emotional intelligence, (2) describe the aggressive behavior of adolescents, and (3) examine the significance of the relationship between emotional intelligence and aggressive behavior of adolescents. This study uses quantitative methods with descriptive correlation types. The population of this study was 300 students selected by Stratified Random Sampling. The instrument used in this study was a Likert scale model questionnaire. Data were analyzed by descriptive statistical techniques and Pearson Product Moment techniques. The research findings show that: (1) adolescent emotional intelligence is in the high category, (2) adolescent aggressive behavior in the moderate category, (3) and there is a significant negative relationship between emotional intelligence and aggressive behavior of adolescents with coefficient correlation -0.431 and level significance of 0,000. This research is important so that aggressive behavior of adolescents can be minimized by emotional intelligence, because adolescents who manage their emotional intelligence are well able to control themselves so they do not take aggressive actions.
\end{abstract}

Keywords: emotional intelligence, aggressive behavior distribution, and reproduction in any medium, provided the original work is properly cited. C2017 by author

\section{PENDAHULUAN}

Masa remaja merupakan salah satu periode dalam rentangan kehidupan manusia (Arnett, 2000). Pada tahap ini remaja akan mengalami berbagai goncangan dan masalah yang berkaitan dengan dirinya dan hubungan sosialnya. Masa remaja merupakan masa transisi dari masa kanak-kanak menuju dewasa, remaja sebagai masa penuh gejolak emosi dan keseimbangan sehingga remaja mudah terpengaruh oleh lingkungan.

Tahap perkembangan remaja merupakan salah satu tahap yang dilalui oleh setiap individu dalam menjalani kehidupannya. Menurut Papalia, E.D, dkk (2013:534) masa remaja merupakan transisi perkembangan antara masa kanak-kanak dan masa dewasa yang mengandung perubahan besar pada fisik, kognitif dan psikososial. Hal ini sesuai dengan yang dikemukakan Santrock (2007:20) bahwa masa remaja sebagai periode transisi perkembangan antara masa kanak-kanak dengan dewasa yang melibatkan perubahan biologis, kognitif dan sosioemosional.

Selain itu, masa remaja juga ditandai dengan emosi yang labil, seperti yang dikemukakan oleh Hurlock (dalam Elida Prayitno, 2006:69) bahwa periode remaja cenderung temperamen atau emosi tinggi, dalam arti emosi negatif mereka lebih mudah muncul. Hal ini disebabkan karena remaja banyak mengalami masalah dalam memenuhi kebutuhan mereka, karena lingkungan tidak mendukung, bahkan menghalangi usaha pemuasan 
kebutuhan-kebutuhan itu. Apabila remaja mengalami situasi yang tidak menyenangkan atau mendapatkan sesuatu yang tidak disenangi, remaja tersebut lebih cenderung menyelesaikan atau menghadapinya dengan emosi yang negatif bahkan agresif. Selanjutnya Crutfield \& Ballachey (dalam Hasballah M. Saad, 2003:14) mengatakan perilaku agresif merupakan semua bentuk perilaku yang diarahkan untuk merusak atau melukai orang lain.

Sejalan dengan itu, Buss (dalam Ivancevich, 2007:264) juga mengemukakan bahwa agresif dapat dikategorikan dalam dimensi fisik, verbal, aktif, pasif, langsung, dan tidak langsung. Bentuk fisik dari agresif dapat melibatkan serangan dengan tinju, mendorong, menampar, menendang, bahkan dengan menggunakan senjata. Bentuk verbal dari agresif ditunjukkan oleh kata-kata, seperti hinaan, makian, gosip, tuduhan, dan lain sebagainya. Agresif aktif menimbulkan bahaya melalui suatu perilaku spesifik, sedangkan agresif pasif dicapai melalui menahan sesuatu yang diinginkan. Bentuk langsung dari agresif adalah ketika orang yang melakukan agresif tersebut yang menimbulkan bahaya, sedangkan dalam agresif tidak langsung orang lain yang menimbulkan bahaya.

Menurut Guswani \& Kawuryan, (2011) faktor-faktor yang mempengaruhi perilaku agresif antara lain: kematangan emosi, kontrol diri, regiulitas, kecerdasan emosi dan pengaruh media. Salah satu faktor yang mempengaruhi perilaku agresif adalah kecerdasan emosi. Goleman (2009:45) menyatakan "kecerdasan emosi merupakan kemampuan emosi yang meliputi kemampuan untuk mengendalikan diri, memiliki daya tahan ketika menghadapi suatu masalah, mampu mengendalikan impuls, memotivasi diri, mampu mengatur suasana hati, kemampuan berempati dan membina hubungan dengan orang lain".

Kecerdasan emosi dapat menempatkan emosi seseorang pada porsi yang tepat, memilah kepuasan dan mengatur suasana hati. Koordinasi suasana hati adalah inti dari hubungan sosial yang baik. Apabila seseorang pandai menyesuaikan diri dengan suasana hati individu yang lain atau dapat berempati, orang tersebut akan memiliki tingkat emosionalitas yang baik dan akan lebih mudah menyesuaikan diri dalam pergaulan sosial serta lingkungannya. Hal ini sesuai dengan pendapat Ary Ginanjar Agustian (2001:44) mengungkapkan bahwa kecerdasan emosi adalah kemampuan merasakan, memahami dan secara efektif menerapkan daya dan kepekaan emosi sebagai sumber energi, emosi, dan koneksi dan pengaruh yang manusiawi.

Selanjutnya, individu yang memiliki kecerdasan emosional dapat dilihat dari ciri-ciri yang ditampilkan melalui perilaku. Goleman (2015:55-57) mengungkapkan ciri-ciri kecerdasan emosional dalam diri seseorang dapat dilihat dari lima wilayah utama sebagai berikut: (1) mengenali emosi sendiri, mengenal diri sendiri, kemampuan untuk memantau perasaan dari waktu ke waktu merupakan hal penting bagi pemahaman diri, (2) mengelola emosi, merupakan kemampuan menyeimbangkan emosi, bahkan menekan emosi, (3) memotivasi diri sendiri, merupakan kecakapan utama, bagaimana individu mampu secara terus-menerus untuk meningkatkan kemampuan yang ada dari waktu ke waktu, (4) mengenal emosi orang lain, dan (5) membina hubungan, menangani emosi orang lain merupakan seni yang mantap untuk menjalin hubungan dengan orang lain.

Dayaksini dan Hudaniyah (2003) juga menjelaskan bahwa kesadaran diri yang rendah bisa memicu orang berperilaku agresif. Rendahnya kesadaran diri dapat menghasilkan perasaan tertentu sehingga seseorang tidak lagi mempertimbangkan orang lain dan merasa tidak memiliki kebutuhan untuk takut terhadap kecaman atau pembalasan atas perilakunya, dan membimbing individu pada keadaan deindividuasi yang mengakibatkan perhatiannya menjadi lebih rendah terhadap pikiran, perasaan, nilai-nilai dan standar perilaku yang dimilikinya.

Idealnya seorang remaja berkembang dengan baik tidak akan menonjolkan perilaku yang mengarah pada perilaku negatif, sejalan dengan pendapat Elida Prayitno (2006:8) tingkahlaku negatif bukan merupakan perkembangan remaja yang normal, remaja yang berkembang dengan baik akan memperlihatkan perilaku yang positif. Perilaku agresif adalah salah satu perilaku yang mengarah pada perilaku negatif. Remaja yang menampilkan perilaku agresif adalah remaja yang perkembangannya terganggu. Perilaku agresif yaitu suatu tindakan yang dilakukan secara sengaja pada individu lain sehingga mengakibatkan sakit fisik dan psikis pada individu lain. Salah satu penelitian yang dilakukan oleh Melisa Yumarlis (2010) mengatakan 10\% agresivitas siswa berada pada kategori sangat tinggi, 40\% agresivitas siswa pada kategori sedang, 30\% agresivitas siswa pada kategori rendah. Hal ini menunjukkan bahwa secara umum agresivitas siswa SMP Negeri 15 Padang berada pada kategori sedang. Selanjutnya penelitian yang dilakukan oleh Triyuni Trisna Watiningsih (2010) mengatakan sebanyak 56,90\% siswa SMA Yayasan Pendidikan Kotamadya Blitar memiliki self esteem sedang, sebanyak 56,90\% siswa SMA Yayasan Pendidikan Kotamadya Blitar memiliki perilaku agresif sedang. 


\section{METODE}

Penelitian ini menggunakan metode kuantitatif dengan pendekatan deskriptif dan korelasional yang bertujuan untuk mendeskripsikan kecerdasan emosi (X) dan perilaku agresif remaja (Y). Populasi penelitian ini siswa kelas X, XI, dan XII MAN 1 Tanah Datar yang berjumlah 300 orang dan sampel sebanyak 178 siswa yang dipilih dengan Stratified Random Sampling. Instrumen yang digunakan adalah Skala Kecerdasan Emosi dan Skala Perilaku Agresif Remaja. Data yang dikumpulkan dianalisis menggunakan statistik desktiptif dan teknik Pearson Product Moment dengan bantuan program SPSS for windows 20.

\section{HASIL}

Berdasarkan pengolahan data yang telah dilakukan, maka data hasil penelitian disajikan dan dianalisis sesuai dengan tujuan penelitian yang diajukan sebelumnya, yaitu (1) mendeskripsikan kecerdasan emosi remaja, (2) mendeskripsikan perilaku agresif remaja dan (3) menguji hubungan kecerdasan emosi dengan perilaku agresif remaja.

Tabel 1. Rekapitulasi Data Hasil Penelitian Kecerdasan Emosi dan Perilaku Agresif Remaja

Persentase $\%$

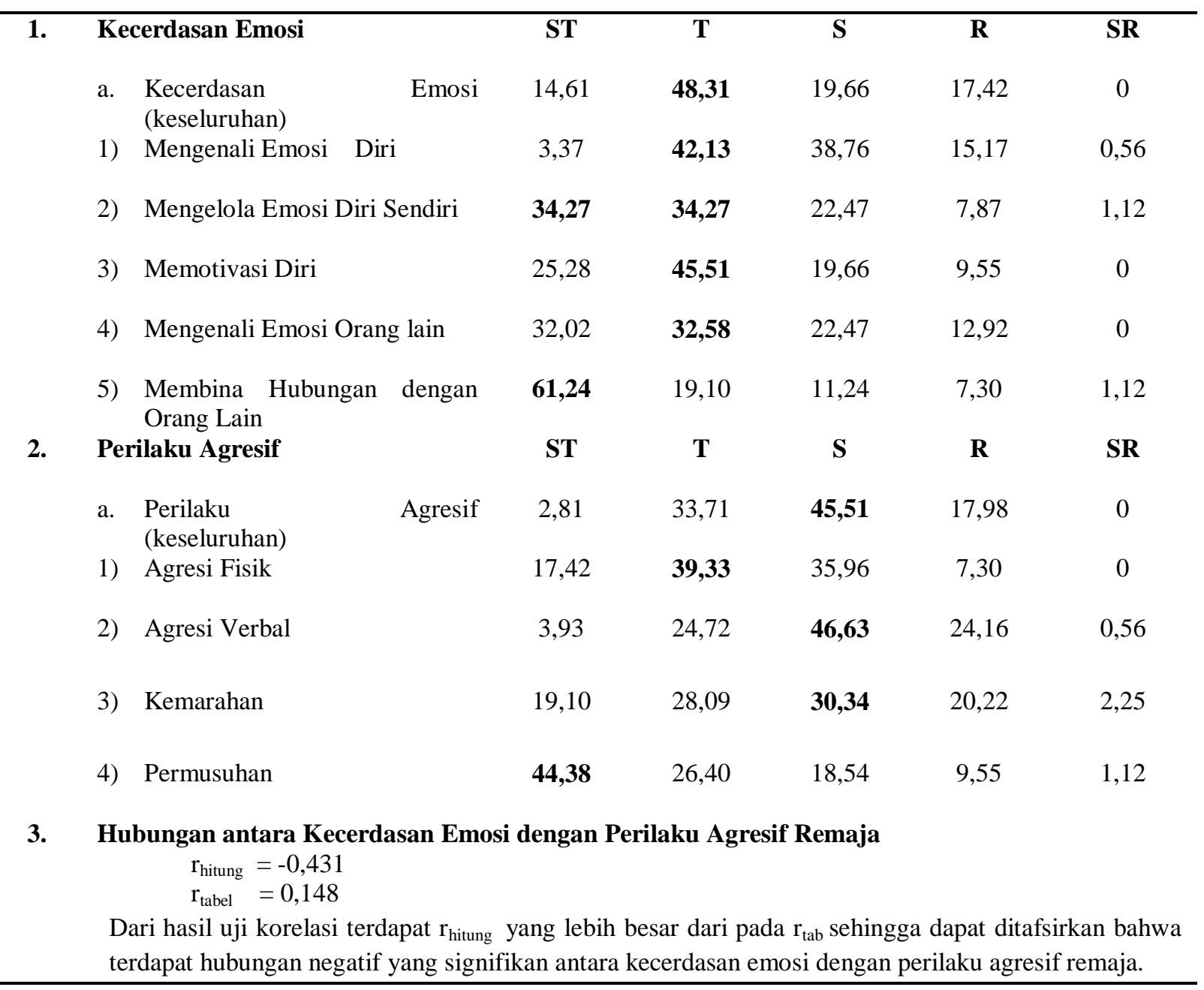




\section{PEMBAHASAN}

\section{Kecerdasan Emosi}

Berdasarkan hasil penelitian diketahui bahwa kecerdasan emosi di MAN 1 Tanah Datar secara keseluruhan berada pada kategori tinggi dengan frekuensi 86 dan persentase 48,31\%. Artinya sebagian besar remaja MAN 1 Tanah Datar memiliki kecerdasan emosi yang tergolong tinggi. Kecerdasan emosi remaja disebabkan oleh kemampuan remaja untuk merasakan dan memahami emosi pada dirinya, peka terhadap emosi orang lain dalam menjalin hubungan dengan orang dan berinteraksi sosial serta dapat mengelola emosi yang dapat digunakan untuk membimbing pikiran untuk mengambil keputusan yang terbaik. Hal ini sesuai dengan pendapat Goleman (2015:55-57) yang menyatakan kecerdasan emosi meliputi kemampuan mengenali emosi diri sendiri, mengelola emosi diri, memotivasi diri, mengenali emosi orang lain dan membina hubungan dengan orang lain.

Dengan kecerdasan emosi, maka seseorang dapat menempatkan emosinya pada keadaan yang tepat, memilah kepuasan dan dapat mengatur suasana hati. Dengan demikian, individu yang memiliki kecerdasan emosi yang baik, apabila memiliki hubungan sosial yang matang, mudah berteman, jenaka, tidak mudah takut atau gelisah, mampu menyesuaikan diri dengan beban stres, serta memiliki kemampuan besar untuk melibatkan diri dengan orang orang atau permasalahan, untuk mengambil tanggung jawab, dan memiliki pandangan moral. Salah satu keberhasilan dalam berkomunikasi adalah adanya rasa percaya diri (Dika, Syahniar \& Marjohan, 2016). Hal ini menandakan bahwa dalam berkomunikasi siswa dapat diterima oleh orang lain, karena keberhasilan komunikasi sebagian besar dipengaruhi oleh kecerdasan emosi. Dengan adanya kecerdasan emosi maka individu akan mampu dalam mengontrol emosi diri dan berusaha menjaga perasaan orang lain.

Dengan demikian, perlu intervensi dari guru BK di sekolah dengan cara membina siswa melalui pengembangan diri pribadi dan sosialnya agar tidak mudah terjerumus ke dalam aksi yang mengarah kepada perilaku agresif dan semisalnya. Dalam menyikapi keadaan ini, guru BK di sekolah memiliki peran yang sangat penting dalam membantu siswa membina kemampuan dalam mempertahankan dan meningkatkan emosi dengan baik sehingga peluang untuk berperilaku agresif di kalangan siswa dapat diminimalisir.

Dari uraian di atas secara umum kecerdasan emosi remaja berada pada kategori tinggi yang artinya remaja mampu mengendalikan kecerdasan emosi dengan baik dalam aspek mengenali emosi diri, mengelola emosi diri sendiri, memotivasi diri, mengenali emosi orang lain dan membina hubungan dengan orang lain, maka remaja harus bisa mempertahankan dan meningkatkan kecerdasan emosinya mengingat berbagai persoalan yang dihadapi remaja dalam berhubungan sosial. Untuk itu guru BK/Konselor sekolah diharapkan memberikan layanan yang tepat dan sesuai dengan kebutuhan remaja mampu agar mempertahankan dan meningkatkan kecerdasan emosinya dengan baik.

\section{Perilaku Agresif}

Berdasarkan hasil penelitian diketahui bahwa perilaku agresif remaja di MAN 1 Tanah Datar secara keseluruhan berada pada kategori sedang dengan frekuensi 81 dan persentase $45,51 \%$. Artinya sebagian besar remaja MAN 1 Tanah Datar memiliki tingkat perilaku agresif yang tergolong sedang. Dengan demikian dapat dipahami bahwa tingkat perilaku agresif remaja relatif sedang yang artinya sebagian remaja melakukan tindakan agresif. Perilaku agresif yang dilakukan oleh remaja disebabkan oleh banyak sekali faktor diantaranya agresi sebagai suatu dorongan, agresi sebagai suatu respon yang dipelajari, ekspresi agresif sebagai katarsis.

Siswa merupakan remaja yang sedang berada pada periode peralihan dan rentan terjadinya perubahan dalam dirinya, salah satunya seperti ketidakseimbangan dan ketidakstabilan emosi, dalam arti prilaku negatif lebih mudah muncul. Hal ini sesuai dengan pendapat Elhesmi, S., Neviyarni, S., \& Ibrahim, I (2013) bahwa pada masa remaja menunjukkan perubahan sikap dan prilaku anak.

Perilaku negatif yang ditunjukkan remaja adalah perilaku agresif. Agresivitas adalah segala bentuk perilaku yang dimaksudkan untuk menyakiti atau melukai orang lain baik secara fisik ataupun psikis. Menurut Buss dan Perry (1992) aspek-aspek dalam prilaku agresif yang timbul pada individu yaitu agresi fisik, agresif verbal, kemarahan dan permusuhan.

Dalam hal ini Guru Bimbingan dan Konseling (BK)/Konselor dapat berperan aktif dalam mencegah dan menangani perilaku agresif tersebut dengan menggunakan berbagai macam layanan BK dan kegiatan pendukung lainnya. Sebelum mencegah perilaku agresif sebaiknya Guru BK/Konselor mengetahui faktor yang menjadi penyebab terjadinya perilaku agresif tersebut. Selain untuk mengetahui faktor penyebab terjadinya perilaku agresif, juga dapat dijadikan sebagai rancangan pembuatan program layanan BK yang akan diberikan oleh Guru BK/Konselor terhadap peserta didik. 
Dari uraian di atas secara umum perilaku agresif remaja berada pada kategori sedang yang artinya sebagian besar remaja melakukan tindakan agresif baik secara fisik, verbal, kemarahan dan permusuhan. Tindakan agresif yang dilakukan remaja yaitu memukul, mendorong, menendang, menghina, memaki, memfitnah, dendam, iri hati, dengki dan lain sebagainya. Tindakan agresif remaja ini harus di atasi agar tidak Untuk itu remaja perlu dibimbing dan diberikan layanan yang tepat dan sesuai oleh guru BK/Konselor sekolah agar remaja mampu meminimalisir perilaku agresifnya terutama pada aspek permusuhan dan agresi fisik.

\section{Hubungan antara Kecerdasan Emosi dengan Perilaku Agresif Remaja}

Hasil yang diperoleh dari pengajuan hipotesis mengungkapkan bahwa terdapat hubungan yang signifikan yang negatif signifikan antara kecerdasan emosi dengan perilaku agresif remaja MAN 1 Tanah Datar. Hubungan yang negatif signifikan ini dapat diartikan, semakin tinggi kecerdasan emosi maka tingkat perilaku agresif semakin rendah. Sebaliknya semakin rendah kecerdasan emosi maka tingkat perilaku agresif semakin tinggi.

Menurut Goleman (2009:45) kecerdasan emosi merupakan kemampuan emosi yang meliputi kemampuan untuk mengendalikan diri, memiliki daya tahan ketika menghadapi suatu masalah, mampu mengendalikan impuls, memotivasi diri, mampu mengatur suasana hati, kemampuan berempati dan membina hubungan dengan orang lain.

Hal yang serupa juga dinyatakan oleh Guswani dan Kawuryan (2011) kecerdasan emosi merupakan salah satu faktor bukan satu-satunya faktor yang mempengaruhi perilaku agresif. Dengan demikian masih ada faktor yang lain yang mempengaruhi perilaku agresif seperti tekanan teman sebaya, pengaruh media kekerasan, faktor amarah, biologis, kesenjangan generasi, proses pendisiplinan yang keliru, frustasi, stress, provokasi, dan alkohol.

Dayaksini \& Hudaniah (2009:178) meyakini bahwa yang sangat berpengaruh terhadap perilaku agresif adalah tujuan atau kesengajaan dalam melakukannya. Seseorang yang hendak berperilaku agresif berfikir bahwa peristiwa yang terjadi secara kebetulan menghasilkan perilaku agresif seseorang yang dengan sengaja menubruk orang lain sehingga orang itu kehilangan keseimbangan dan jatuh, maka perilaku orang tersebut dapat dikatakan sebagai perilaku agresif.

Dari beberapa pendapat ahli di atas dapat disimpulkan bahwa indikasi yang cerdas secara emosi adalah dapat mereka yang dapat memahami terlebih dahulu situasi yang sedang dihadapinya sebelum bertindak, mereka tidak akan bereaksi seperti anak-anak yang cenderung lebih mengedepankan emosinya ketimbang pemikiran. Namun tidak jarang di sekolah, sebagian remaja lebih mengedepankan emosi negatifnya dalam menghadapi situasi yang kurang menguntungkan baginya, seperti marah ketika kesal terhadap teman, berkatakata kasar, bahkan ada yang merusak benda disekitarnya. Sehingga remaja yang belum mampu mengelola kecerdasan emosinya mudah terjerumus ke dalam perilaku negatif seperti agresif. Dalam menyikapi keadaan ini, guru BK di sekolah memiliki peran yang sangat penting dalam membantu remaja membina kemampuan dalam mengelola kecerdasan emosinya dengan baik sehingga peluang berperilaku agresif di kalangan siswa dapat diminimalisir.

Berdasarkan uraian di atas terdapat hubungan yang negatif signifikan antara kecerdasan emosi dengan perilaku agresif remaja. Artinya semakin tinggi kecerdasan emosi remaja maka semakin rendah tingkat perilaku agresif remaja. Hal ini dapat terjadi karena kecerdasan emosi merupakan salah satu faktor yang mempengaruhi perilaku agresif remaja, tetapi bukan satu-satunya faktor yang mempengaruhi perilaku agresif remaja. Jadi guru BK/Konselor sekolah mempunyai peranan penting di sekolah untuk mencegah timbulnya perilaku agresif dikalangan remaja dengan cara mengendalikan kecerdasan emosi remaja dengan baik, dan faktor-faktor lain yang dapat memicu terjadinya perilaku agresif remaja.

\section{Implikasinya terhadap Layanan Bimbingan dan Konseling}

Berdasarkan hasil penelitian yang diperoleh, maka program pelayanan BK yang dapat diberikan konselor kepada remaja dalam rangka mencapai keberhasilan untuk menciptakan serta mempertahankan kecerdasan emosi remaja yang berada pada kategori tinggi dan meminimalisir perilaku agresif remaja yang masih berada pada kategori sedang di MAN 1 Tanah Datar.

Materi layanan yang dapat diberikan yaitu: bagaimana cara memahami penyebab timbulnya emosi dalam diri remaja, cara meningkatkan kepercayaan diri remaja, cara mengendalikan emosi, kiat-kiat meningkatkan motivasi berprestasi remaja, pengenalan tentang macam-macam emosi dan upaya penanggulangannya, kemampuan dalam berkomunikasi, pengenalan tentang kekuatan dan kelemahan diri serta upaya pengembangan dan penanggulangannya, cara berkomunikasi yang efektif dalam pergaulan, dampak yang ditimbulkan dari 
agresi fisik, cara meredam kemarahan, cara menghindari sikap iri dan dengki dalam diri, dampak yang dtimbulkan dari agresi fisik baik terhadap diri sendiri maupun orang lain, dan bahaya yang ditimbulkan dari sikap permusuhan, cara menghindari perilaku agresi fisik, komunikasi yang positif antar remaja, penanggulangan kemarahan dalam diri, kiat menghindari sikap iri hati dan dengki, cara meminimalisir agresi fisik remaja, cara menghindari komunikasi negatif, serta cara mengelola emosi dengan baik agar tidak timbul kemarahan dan rasa iri hati dan dengki terhadap orang lain.

Dari uraian di atas materi layanan tersebut dapat diberikan oleh guru Bk melalui jenis layanan sebagai berikut.

a. Layanan Informasi

Prayitno dan Erman Amti (2004:259) menyatakan bahwa layanan informasi merupakan salah satu layanan bimbingan dan konseling yang dimaksudkan untuk memberikan pemahaman kepada individu tentang berbagai hal yang diperlukan untuk menjalani suatu tugas atau kegiatan, atau untuk menentukan arah suatu tujuan atau rencana yang dikehendaki.

Adapun materi layanan yang dapat diberikan yaitu sebagai berikut: (1) untuk mempertahankan dan meningkatkan kecerdasan emosi remaja materi layanan informasi yang dapat diberikan yaitu: bagimana cara memahami penyebab timbulnya emosi dalam diri remaja, cara meningkatkan kepercaya diri remaja, cara mengendalikan emosi, kiat-kiat meningkatkan motivasi berprestasi remaja, (2) untuk meminimalisir perilaku agresif remaja materi layanan informasi yang dapat diberikan yaitu: komunikasi yang positif, dampak yang dtimbulkan dari agresi fisik, cara meredam kemarahan, cara menghindari sikap iri dan dengki dalam diri.

b. Layanan Konseling Individual

Layanan konseling individual menurut Prayitno dan Erman Amti (2004:288) merupalan salah satu layanan bimbingan dan konseling yang mana terdapat hubungan langsung secara tatap muka antara konselor dengan klien dalam proses konseling. Pada layanan ini konselor membantu klien untuk mengentaskan permasalahan yang dialami oleh klien. Dalam hal ini, layanan konseling individual dapat diberikan kepada remaja sebagai berikut: (1) untuk mempertahankan dan meningkatkan kecerdasan emosi remaja materi layanan konseling perorangan yang dapat diberikan yaitu: pengenalan tentang macam-macam emosi dan upaya penanggulangannya, kemampuan dalam berkomunikasi, pengenalan tentang kekuatan dan kelemahan diri serta upaya pengembangan dan penanggulangannya, (2) untuk meminimalisir perilaku agresif remaja materi layanan konseling perorangan yang dapat diberikan yaitu: dampak yang dtimbulkan dari agresi fisik baik terhadap diri sendiri maupun orang lain, dan bahaya yang ditimbulkan dari sikap permusuhan.

Dorongan untuk berperilaku agresif yang dimiliki remaja haruslah dientaskan oleh guru $\mathrm{BK} /$ Konselor yang mana jika perilaku agresif siswa tidak segera dientaskan maka akan membahayakan diri sendiri dan orang lain yang menjadi subjek perilaku agresif remaja tersebut.

c. Layanan Bimbingan Kelompok

Layanan bimbingan kelompok menurut Prayitno dan Erman Amti (2004:309) merupakan layanan bimbingan yang diberikan dalam suasana kelompok. Layanan bimbingan kelompok memungkinkan sejumlah peserta didik secara bersama-sama melalui dinamika kelompok memperoleh berbagai bahan dari narasumber tertentu (terutama dari guru pembimbing) dan/atau membahas secara bersama-sama pokok bahasan atau topik tertentu untuk perkembangan dirinya.

Dengan bimbingan kelompok ini, guru BK/Konselor bisa memberikan topik bahasan terkait dengan kecerdasan emosi dan perilaku agresif remaja sebagai berikut: (1) untuk mempertahankan dan meningkatkan kecerdasan emosi remaja materi layanan bimbingan kelompok yang dapat diberikan yaitu: cara mengendalikan emosi, cara meningkatkan kepercayaan diri, cara berkomunikasi yang efektif dalam pergaulan, dan (2) untuk meminimalisir perilaku agresif remaja materi layanan konseling perorangan yang dapat diberikan yaitu: cara menghindari perilaku agresi fisik, komunikasi yang positif antar remaja, penanggulangan kemarahan dalam diri, dan kiat menghindari sikap iri hati dan dengki.

d. Layanan Konseling Kelompok

Layanan konseling kelompok menurut Prayitno dan Erman Amti (2004:311) merupakan layanan konseling perorangan yang dilaksanakan dalam suasana kelompok. Melalui adanya dinamika interaksi sosial yang terjadi antara anggota kelompok, masalah yang dialami oleh masing-masing individu anggota kelompok dicoba untuk dientaskan. Dalam konseling kelompok ini, Guru BK/Konselor dan siswa bisa bersama-sama membantu menyelesaikan permasalahan yang mengganggu siswa.

Materi layanan konseling kelompok yang dapat diberikan yaitu memahami penyebab timbulnya emosi, cara meminimalisir agresi fisik remaja, cara menghindari komunikasi negatif, cara mengelola emosi dengan baik agar tidak timbul kemarahan dan rasa iri hati dan dengki terhadap orang lain. 
Jadi melalui semua layanan tersebut guru BK memiliki peran yang sangat penting dalam membantu remaja dalam mengelola kecerdasan emosinya dengan baik sehingga peluang untuk berperilaku agresif dikalangan remaja dapat diminimalisir.

\section{KESIMPULAN}

Berdasarkan hasil penelitian, maka penelitian ini dapat disimpulkan sebagai berikut: (1) Kecerdasan emosi remaja MAN 1 Tanah Datar sebagian besar berada pada kategori tinggi. Ditinjau dari aspek mengenali emosi diri, memotivasi diri sendiri yang juga berada pada kategori sedang, mengelola emosi diri sendiri berada pada kategori sangat tinggi dan tinggi dan membina hubungan dengan orang lain berada pada kategori sangat tinggi. Artinya, sebagian besar remaja memiliki tingkat kecerdasan emosi yang baik. Oleh karena itu, guru BK dapat menjaga dan mempertahankan situasi yang telah tercipta melalui layanan informasi dan bimbingan kelompok dengan membahas fenomena yang berkaitan dengan kecerdasan emosi. (2) Berdasarkan hasil penelitian, tingkat perilaku agresif remaja MAN 1 Tanah Datar sebagian besar berada pada kategori sedang. Ditinjau dari aspek agresi verbal dan kemarahan yang juga berada pada kategori sedang, agresi fisik berada pada kategori tinggi dan permusuhan berada pada kategori sangat tinggi. Artinya, sebagian besar remaja melakukan tindakan agresif. Oleh karena itu, guru BK dapat memberikan layanan informasi tentang pengendalian kecerdasan emosi remaja dan kontrol diri untuk meminimalisir perilaku agresif. (3) Terdapat hubungan yang negatif signifikan antara kecerdasan emosi dengan perilaku agresif remaja di MAN 1 Tanah Datar dengan koefisien korelasi -0,431 dan memiliki hubungan yang tergolong cukup kuat. Artinya, semakin tinggi kecerdasan emosi maka semakin rendah tingkat perilaku agresif remaja, begitu sebaliknya semakin rendah kecerdasan emosi maka semakin tinggi tingkat perilaku agresif remaja.

\section{REFERENSI}

Alex Sobur. (2011). Psikologi Umum. Bandung: Pustaka Setia.

Ary Ginanjar Agustian. (2001). Rahasia Sukses Membangun Kecerdasan Emosional dan Spiritual (ESQ). Jakarta: Arya.

Arnett, J. J. (2000). Emerging Adulthood: A Theory of Development from The Late Teens Through The Twenties. American psychologist, Volume 5, nomor 55, 469.

Buss, A. H., \& Perry, M. (1992). Personality Processes and Individual The Aggression Questionnaire. Journal of Personality and Social Psychology, Volume 3, nomor 63, 452-459.

Dika Sahputra, Syahniar \& Marjohan. (2016). Kontribusi Kepercayaan Diri dan Kecerdasan Emosi terhadap Komunikasi Interpersonal Siswa serta Implikasinya dalam Pelayanan Bimbingan dan Konseling. Jurnal Ilmiah Konseling,Volume 5, Nomor 3, 182-193.

Elida Prayitno. (2006). Psikologi Perkembangan Remaja. Padang: FIP UNP.

Goleman, Daniel. (2009). Emotional Intelligence. Jakarta: Gramedia Pustaka Utama.

Goleman, Daniel. 2015. Emotional Intelligence. Jakarta: Gramedia Pustaka Utama.

Guswani, A. M. \& Kawuryan, F. (2011). Perilaku Agresif pada Mahasiswa Ditinjau dari Kematangan Emosi. Jurnal psikologi Pitutur, Volume 1, nomor 2, 86-92.

Hasballah, M. Saad. (2003). Perkelahian antar Pelajar: Potret Siswa SMU di DKI Jakarta. Yogyakarta: Galang Press.

Ivancevich, John M. Dkk. (2007). Perilaku dan Manajemen Organisasi. Jakarta: Erlangga.

Jhon, W. Santrock. (2007). Psikologi Perkembangan. Edisi 11 Jilid 1. Jakarta: Erlangga.

Krahe, B. (2005). Perilaku Agresif. Yogyakarta: Pustaka Pelajar Offset.

Melisa Yumarlis. (2010). Hubungan Keluarga Harmonis dengan Agresivitas Siswa di SMP Negeri 15 Padang. Skripsi. Tidak diterbitkan. Padang: FIP UNP.

Papalia, Diane E., Old, S.W., \& Feldman. (2013). Human Development. Jakarta: Salemba Humanika.

Prayitno \& Erman Amti. (2004). Dasar-Dasar Bimbingan dan Konseling. Jakarta: Rineka Cipta.

Shudra Elhesmi, Neviyarni, Indra Ibrahim. (2013). Peran Guru Mata Pelajaran dalam Mencegah Tawuran antar Pelajar. Jurnal Ilmiah Konseling, Volume 2, Nomor 3, 7-15.

Tri Dayaksini dan Hudaniah. (2003). Psikologi Sosial. Malang: UMM Press.

Tri Dayaksini dan Hudaniah. (2009). Psikologi Sosial. Malang: UMM Press.

Triyuni, T. W. (2010). "Hubungan antara Self Esteem dan Perilaku Agresif Siswa SMA Yayasan Pendidikan Kotamadya Blitar”. Skripsi. Tidak diterbitkan. Malang: Universitas Malang. 